\title{
Systems biology approaches to understanding Epithelial Mesenchymal Transition (EMT) in mucosal remodeling and signaling in asthma
}

\author{
Talha ljaz ${ }^{1 \dagger}$, Konrad Pazdrak ${ }^{1,2,3 \dagger}$, Mridul Kalita ${ }^{2,4 \dagger}$, Rolf Konig ${ }^{2,5}$, Sanjeev Choudhary ${ }^{1,2,5}$, Bing Tian ${ }^{4}$, \\ Istvan Boldogh ${ }^{1,2,5}$ and Allan R Brasier ${ }^{2,3,4^{*}}$
}

\begin{abstract}
A pathological hallmark of asthma is chronic injury and repair, producing dysfunction of the epithelial barrier function. In this setting, increased oxidative stress, growth factor- and cytokine stimulation, together with extracellular matrix contact produces transcriptional reprogramming of the epithelial cell. This process results in epithelial-mesenchymal transition (EMT), a cellular state associated with loss of epithelial polarity, expression of mesenchymal markers, enhanced mobility and extracellular matrix remodeling. As a result, the cellular biology of the EMT state produces characteristic changes seen in severe, refractory asthma: myofibroblast expansion, epithelial trans-differentiation and subepithelial fibrosis. EMT also induces profound changes in epithelial responsiveness that affects innate immune signaling that may have impact on the adaptive immune response and effectiveness of glucocorticoid therapy in severe asthma. We discuss how this complex phenotype is beginning to be understood using systems biology-level approaches through perturbations coupled with high throughput profiling and computational modeling. Understanding the distinct changes induced by EMT at the systems level may provide translational strategies to reverse the altered signaling and physiology of refractory asthma.
\end{abstract}

Keywords: EMT, Inflammation, NF-KB, TGFß, Eosinophils, Systems biology, Innate immunity

Currently it is estimated that over 300 million adults and children suffer from asthma, representing a major public health problem worldwide. Over the past two decades, there has been a rise in asthma prevalence, such that about $8 \%$ of the population, more than 25 million Americans, were affected in 2010 [1]. Asthma is a heterogeneous disease whose presentation, clinical course, and response to therapy is determined by distinct pathobiological processes [2]. Two prominent asthma pathological processes are chronic inflammation and airway remodeling; these processes lead to the variable clinical manifestations characteristic of this syndrome [3]. Of these pathobiological processes, airway remodeling remains refractory to front-line glucocorticoid suppression therapy, and is associated with a subtype of asthma

\footnotetext{
* Correspondence: arbrasie@utmb.edu

${ }^{\dagger}$ Equal contributors

${ }^{2}$ Sealy Center for Molecular Medicine, The University of Texas Medical

Branch, 301 University Blvd, Galveston 77555-1060, Texas, USA

${ }^{3}$ Institute for Translational Sciences, The University of Texas Medical Branch,

301 University Blvd, Galveston 77555-1060, Texas, USA

Full list of author information is available at the end of the article
}

known as severe asthma. This subtype is associated with enhanced morbidity and accounts for disproportionate health care costs [4].

Recent exciting work has yielded insight into the dynamic and central role of the epithelium in asthmatic inflammation and remodeling. In this review, we discuss the cellular biology of an epithelial transcriptional reprogramming event known as epithelial-mesenchymal transition (EMT). Specifically, we examine the current knowledge of how growth factors and inflammation interface to produce EMT, of the role of innate immune cells in this process, and phenotypic modulation by the NF- $\mathrm{KB}$ signaling pathway. Due to the complexity of interacting signals and consequent global transcriptional reprogramming, systemslevel studies are needed to fully understand critical pathways affected by EMT. The "systems" concept relies on global, experimental measurements of the genome, transcriptome, proteome, metabolome, and epigenome in response to external perturbation. One advantage of this approach is that it makes no a priori assumptions about the mechanisms underlying the response, allowing for the 
identification of new and less expected findings [5]. Systems biology has already provided new insights about the interaction between genes and the environment in asthma development [6], and environmental control of gene expression networks [7]. Here, we review findings of systems level perturbations and computational modeling that have shed light on how EMT produces dysregulation of the innate immune signaling pathway and we discuss how future system level studies will lead to potentially new translational interventions focused on modifying the reprogramming of the asthmatic epithelium.

\section{The epithelium is a central component of airway inflammation and remodeling}

The airway mucosal barrier is produced by a relatively impermeable epithelial sheet connected by tight junctions that restrict fluid loss and limit inhaled particulate access to the internal milieu. The airway mucosa is a regionally diverse spectrum of highly differentiated epithelial cell types, each playing a specialized role in normal pulmonary function and host defense. For example, flattened simple squamous type I pneumocytes promote gas exchange, provide a barrier to minimize water loss, and prevent pathogens and toxins from access to the internal architecture; secretory goblet cells produce and secrete protective mucins into the airway lining fluid; ciliated epithelial cells produce protective epithelial lining fluid and mucociliary escalator for particulate clearance; and type II pneumocytes secrete surfactants responsible for maintaining alveolar patency [8]. In pseudostratified columnar epithelial tissue, basal epithelial cells serve a regenerative function, being responsible for transdifferentiation to repopulate ciliated epithelia, and Clara and goblet cell populations in response to injury or senescence [8].

Maintenance of epithelial integrity is critical to normal cellular signaling, pulmonary homeostasis, and response to toxicants and allergen exposures. Moreover, this dynamic and plastic cell type plays a key role in initiating innate signaling programs in response to physical, chemical and biological challenge through coordinating cytokine and defensin release, and secreting alarmins and Th2-differentiating cytokines [9]. Despite intense study of the Th2 polarization hypothesis [3,10], a body of evidence points to a disruption of the epithelial mucosal barrier and its chronic regenerative process as playing a key pathogenic role in diverse forms of asthma.

Asthma is disease driven, in part, by epithelial injury and repair. Representing the principal cell type between the environment and internal milieu, the epithelial cell not only plays a critical role in the activation and coordination of the innate immune response, but also in tolerance and control of airway hyper-reactivity. It is well established that increased epithelial cell fragility with attendant denudation/shedding of epithelial cells and the consequent disruption of its barrier function enhances allergic sensitization [8]. CC chemokines CCL2, CCL20 and IL-12p40 produced by stimulated epithelial cells activate tissue-resident dendritic cells to produce Th2 polarization characteristic of asthma [3,11]. The loss of apical polarity, increased Goblet cell number (metaplasia) and expansion of the myofibroblast population are characteristic histological features of severe asthma. In animal studies, cellular lineage experiments have shown that epithelial cells contribute significantly to the myofibroblast population [12]. These data suggest that the epithelium plays significant pathogenic roles in the genesis and maintenance of reactive airway disease [9].

\section{Inducible epithelial phenotypes: Epithelial- Mesenchymal Transition (EMT) and transdifferentiation}

Under normal conditions, the airway epithelial cells signal to an attenuated sheath of subepithelial mesenchymal cells, forming an epithelial-mesenchymal unit (EMU). Integrity of the EMU depends on growth factors secreted from epithelial cells; growth factor secretion is rapidly increased in response to epithelial injury to promote regeneration of this critical mucosal surface [13]. Injury, subsequent inflammation and the loss of epithelial basement membrane integrity also promote epithelial cell activation by extracellular matrix-associated factors. These resident factors include the growth factors epidermal growth factor (EGF), fibroblast growth factor (FGF), and TGF $\beta$, whose actions are modified by innate immune cytokines (such as IL-6, IL-1 $\beta$, MCP-1 and RANTES) produced by epithelial and tissue resident leukocytes $[9,14]$. These factors transform specialized epithelial cells to become motile, fibroblast-like cells; this process is referred to as type II EMT [15], a response central to repair after tissue injury. In addition to TGF $\beta$, hypoxia is a strong inducer of EMT in kidney and lung epithelia [16,17]. Reactive oxygen species (ROS) produced in hypoxic settings are as potent inducer of EMT as that of TGF $\beta[16,18]$. EMT can also be initiated by other growth factors such as FGF-2, EGF, and connective tissue growth factor (CTGF) [19].

Because TGF $\beta$ is the most potent and most well described inducer of EMT, we will discuss its role in modifying the airway epithelia in detail. In the airway mucosa, TGF $\beta$ induced type II EMT leads to disruption of mucosal barrier function by inducing the loss of apical polarity, reduced epithelial cadherin (ECad) and disruption of epithelial adherens junctions (Figure $1 ;[9,10])$. In addition, type II EMT enables transformed epithelial cells to express $\alpha$-SMA stress fibers and intermediate filament vimentin, to produce ECM through secretion of collagen and fibronectin, and to increase expression of matrix metalloproteinases (MMPs) to promote airway remodeling. Finally, EMT also produces complex alterations in the innate immune response [20], a 


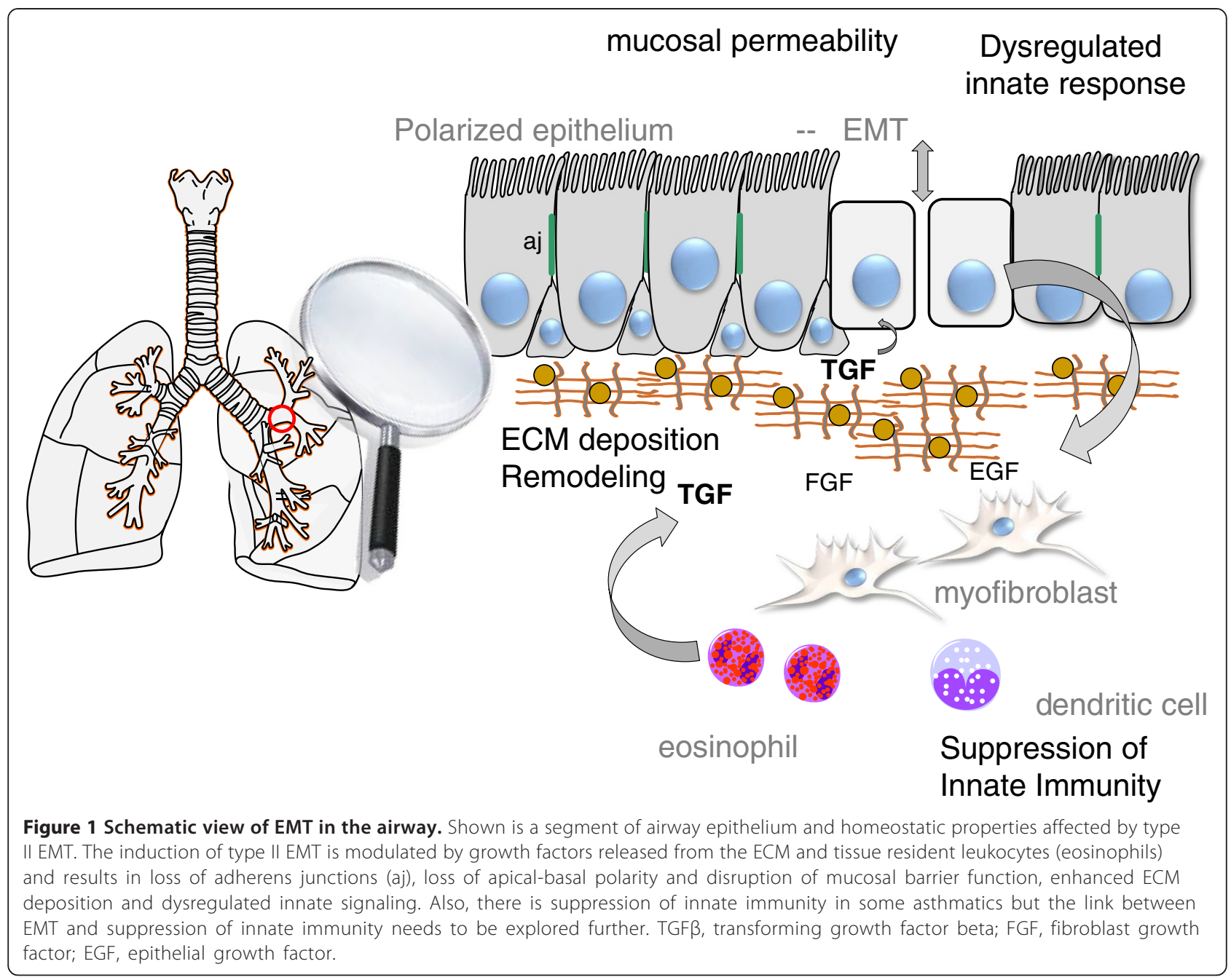

point discussed in detail below. Although type II EMT may be a protective mechanism for tissue repair, excessive and prolonged EMT processes can lead to fibrosis and organ damage as observed in lung [12], liver [21] and kidney fibrosis [22].

Other injury-induced epithelial differentiation paradigms may represent "formes frustes" of EMT. Chronic stimulation with growth factors EGF and amphiregulin, modified by Th2-derived IL-4 and IL-13 cytokines are thought to be responsible for expansion of the mucus-producing Goblet cell population [9]. Goblet cell hyperplasia is the product of trans-differentiation of ciliated and Clara cells. Goblet cells are responsible for expression of MUC5A and MUC5B, glycoconjugates that alter the hydro-elastic properties of mucus in asthma. In this way, stressed epithelial cells within the inflammatory milieu of airways disease are induced to undergo distinct phenotypic switches in ways that fundamentally alter the normal function of the epithelium and play an important role in airway remodeling in asthma.

\section{EMT in asthma}

In asthmatic patients, the airway is fragile with decreased cell-to-cell adhesion, a process due, in part, to reduced ECad expression [23]. Immunoreactivity for TGF $\beta$ and its activated intracellular pathway protein, phospho-Smad2 (p-Smad2), are increased in mucosal biopsies suggesting the presence of active TGF $\beta$ signaling in asthmatic epithelium [24-26]. These and other lines of evidence suggest that EMT plays an important role in pathogenesis of subtypes of asthma [14,27]. Isolated human primary airway epithelial cells from asthmatics lose zona occludin-1 (ZO-1) expression at lower TGF $\beta$ concentrations than that required for normal epithelial cells [28]. In studies of pseudostratified columnar epithelial cells cultured in an air-liquid interface, TGF $\beta$-induced EMT occurs in the basal cell layer, a stem-cell like population involved in trans-differentiation of numerous epithelial cell types [28]. Evidence of detrimental effects of TGF $\beta$ in the lung comes from mouse models where 
instillation of TGF $\beta 1$ into lungs or ectopic expression in the airway epithelium using adenovirus vectors induces airway collagen mRNA and protein deposition [29]. Consequently, neutralization of TGF $\beta$ reduces pulmonary fibrosis, collagen deposition and smooth muscle proliferation [30]. Accumulation of TGF $\beta$ in the bronchoalveolar lavage fluid of chronic asthma patients as well as in sensitized experimental animals challenged with OVA suggests a critical role of TGF $\beta$ in airway remodeling and lung EMT $[28,31,32]$. These data suggest that there is dysregulated TGF $\beta$ signaling in asthmatics and allergic airways which leads to disruption of the epithelial barrier function, mucosal remodeling and fibrosis.

\section{Signaling pathways producing EMT}

The molecular signaling of how TGF $\beta 1$ initiates EMT has been studied in some detail (Figure 2). Free TGF $\beta$ binds to TGF $\beta$ receptor type II (TGF $\beta$ RII), a transmembrane serine, threonine kinase that recruits and phosphorylates TGF $\beta R I$. In the canonical pathway, the activated TGF $\beta$ RI/II complex then recruits Smads 2/3, cytoplasmic transcription factors that are, in turn, phosphorylated by TGF $\beta R I$ on serine residues. Phosphorylated Smad2/3 binds to Smad4 and the complex then translocates to the nucleus. The activated Smad 2/3/4 trimer binds to Smad-binding elements in the regulatory regions of junB and c-Jun, and modulates transcription with other coactivators including the cAMPresponse element binding protein (CBP)/p300 histone acetyltransferases [33].

TGF $\beta 1$ binding to its receptors also stimulates noncanonical signaling pathways including PI3K/Akt, Ras small GTPases, Wnt/ $\beta$-catenin, ERK, p38, and JNK. Although Smad and non-Smad pathways are both activated by TGF $\beta$, it is difficult to distinctly separate the actions of Smads from non-Smad proteins since there is significant cross-talk between the signaling arms with Smads regulating some non-canonical pathways and vice versa [34]. In most instances, Smad-dependant signaling is dominant in mediating EMT but non-Smad proteins are required to complete the cellular transformation.

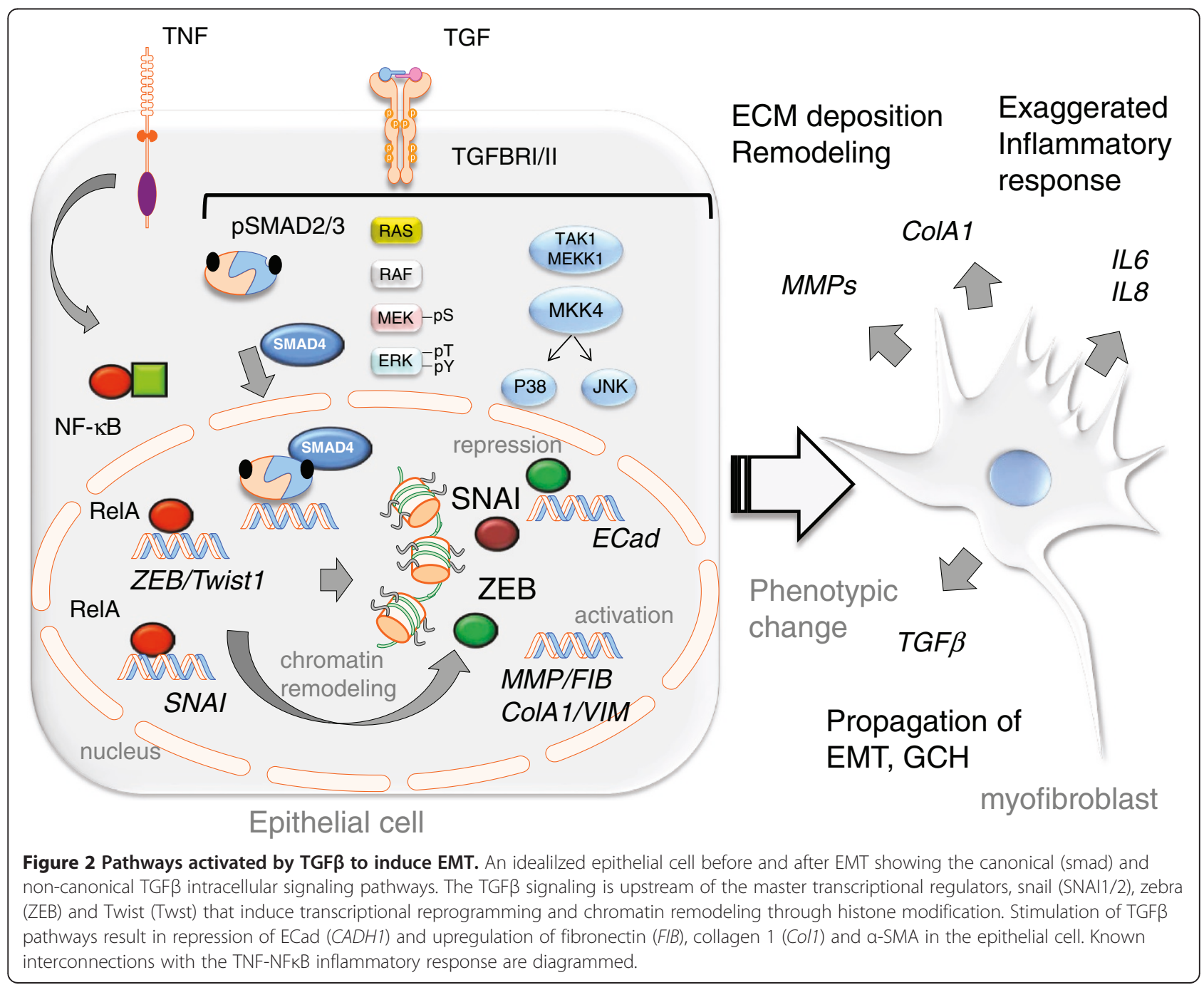


Activation of all three MAPKs leads to cell proliferation, but production of fibronectin is dependent on ERK1/2 and JNK [35]. Mechanistically, it has been demonstrated in a fibrosarcoma cell line that TGF $\beta 1$ activates MAPK4-JNK1, leading to dimerization of the c-Jun and ATF2 transcription factor to initiate transcription of the fibronectin gene [36]. Recent findings in Non-Small Cell Lung Cancer cell lines indicate that TGF $\beta 1$ induced phospho-Erk1/2 mediates a decrease in ECad and an increase in fibronectin expression [37]. Inhibition of JNK, p38 and Akt activities without affecting Smad phosphorylation blocks TGF $\beta 1$ induced $\alpha$-SMA, SNAI1 and collagen $I$ in primary alveolar epithelial cells [38]. Another important non-Smad pathway linking epithelial tight junctions to cytoskeletal changes is the $\beta$-catenin pathway. TGF $\beta 1$ stimulation causes an increase in $\alpha$-SMA via SMAD3- $\beta$-catenin-CBP interaction on the $\alpha$-SMA promoter [39]. $\beta$-catenin is part of the complex that mediates binding of ECad to the actin cytoskeleton. Therefore, downregulation of ECad allows for more availability of $\beta$-catenin to bind to Smads, thus providing a unifying mechanism by which epithelial cells lose their apical polarity and undergo cytoskeleton rearrangement to become motile myofibroblasts.

Currently, it is thought that three families of transcription factors function as key regulators of EMT: snail (SNAI)1/2, zebra (ZEB) $1 / 2$, and Twist $1 / 2$ families [40]. In the canonical pathway, TGF $\beta$-stimulation upregulates SNAI expression via Smad3/4. A SNAI1-smad3/4 complex then binds to regulatory promoter regions of ECad and ZO-1, leading to their repression [41]. Smad signaling also increases ZEB1/2, a transcriptional repressor of the miR-200 family of micro RNAs. The mir-200 family represses translation of ZEB1/2, TGF $\beta R I$ and Smad2. In this manner, miR-200 repression by ZEB1/2 promotes EMT by increasing TGBR mediated signaling [42]. In addition, these transcription factors control the expression of matrix metalloproteinases (MMPs) and ECM proteins such as collagens [40].

\section{Modulators of the EMT program}

Several studies suggest that the ability of TGF $\beta$ to induce EMT is modulated by innate cytokine stimulation, morphogen signaling, allergen exposure and through ECM interactions. Studies of transformed alveolar basal epithelial cells show that TGF $\beta$-induced EMT is accelerated by the presence of members of the proinflammatory TNF/ IL-1 superfamily of cytokines [43-45]. TNF/ IL-1 through intracellular adapters trigger the innate immune response activating downstream Ras GTPase, p38 MAPK and JNK, key components of the noncanonical TGF $\beta$ signaling pathway (Figure 2). Additionally, IL-1/TNF controls NF-kB, a master regulator of airway inflammation [46] that regulates a 4,000 member gene network mediating anti-apoptosis, inflammation, and adaptive immunity $[47,48]$. NF-kB has been identified as a key regulator of the core EMT program, deserving specific mention. In studies of cancerassociated (so-called type III) EMT, NF-kB is required for growth factor-induced SNAI expression by directly inducing expression of the SNAI gene [49]. Similarly, NF-кB upregulates the ZEB1/2 transcription factors that mediate transcriptional silencing of the ECad gene and upregulation of the vimentin (VIM) promoter. In a similar manner, TNFinducible Twist1 expression is mediated by NF- $\mathrm{B}$ [50], explaining, in part, how the IL-1/TNF superfamily of cytokines mediates EMT. Other exciting studies have shown that activated NF- $\mathrm{kB}$ may also directly bind and stabilize SNAI, promoting its pro-EMT activity [51]. In addition to the well described TNF/IL-1 ligands, the superfamily member LIGHT (TNFSF14) is a $\mathrm{T}$ cell coactivator that mediates chronic airway inflammation and is associated with asthma disease severity [52]. LIGHT modulates TGF- $\beta 1$-induced EMT by suppressing E-cadherin and enhancing vimentin expression [53]. Interestingly, LIGHT can also induce EMT independently from that of the TGF- $\beta 1$ pathway through activation of Erk1/2 signaling [53]. Together these data indicate that TNF/IL-1 superfamily through NF- $\mathrm{kB}$ signaling plays a central, upstream coordinating role in EMT through both transcriptional and post-transcriptional actions.

The actions of TGF $\beta$ on EMT are further controlled by the Notch pathway, a highly conserved morphen control pathway involved in epithelial intercellular communication and cell fate specification. In cultured rat alveolar epithelial cells, Notch activation increases the expression of $\alpha$-SMA, collagen I and vimentin and decreases expression of epithelial markers. Notch promotes EMT in airway epithelia by increasing expression of TGF $\beta$ ligands and inducing myofibroblast differentiation of alveolar epithelial cells via the TGF $\beta$-Smad3 pathway [54].

Vascular endothelial growth factor (VEGF), matrix metalloproteinase-9 (MMP-9), and Th2-type cytokines (IL$5,-13,-4$ and -9 ) produced by adaptive immune cells in the lung have also been observed to modulate EMT [55-58]. Moreover, the pro-inflammatory IL-17A cytokine directly regulates EMT and collagen synthesis in a TGF $\beta 1$ dependent process [59]. Neutralizing IL-17A promotes autophagy and attenuates pulmonary fibrosis [59]. This latter mechanism may be important in the pathogenesis of neutrophilic asthma, a subtype of severe steroid refractory asthma characterized by Th17-mediated neutrophilic inflammation.

The ECM is an interlocking mesh of collagens, elastic fibers and glycoproteins that plays a critical role in epithelial polarization, proliferation and signaling [60]. Dynamic remodeling of the ECM in response to injury releases local depots of TGF to stimulate proliferation, repair and EMT. In addition, the composition and 
rigidity of the ECM is another important modulator of epithelial cell signaling and function. Exposure of primary alveolar cells to fibronectin or fibrin led to robust EMT, a phenomenon dependent on $\alpha \mathrm{V} \beta 6$ integrin [12]. In a follow-up study, deletion of $\alpha 3$ integrin in lung epithelium prevented mice from developing fibrosis and led to a decrease in myofibroblast population and collagen I expression after bleomycin injury [61]. These findings strongly suggest that EMT is regulated by contextual factors such as cytokines and ECM interactions through integrin signaling.

Finally, extrinsic environmental stimuli can induce EMT. One prominent example is the house dust mite aero-allergen; exposure to house dust mite potentiates TGF $\beta$-induced EMT of airway epithelial cells by stimulating myosin light chain phosphorylation and actin reorganization and enhanced $\beta$-catenin signaling [62]. This is mechanistically important because the $\beta$-cateninWnt pathway regulates expression of SNAI2/Slug a transcriptional repressor of ECad. Infection with Respiratory Syncytial Virus (RSV), a paramyxovirus widely considered a risk factor for development of allergic asthma later in life, is also characterized by increased expression of SNAI1 and TGF $\beta 1$, master regulators of EMT [63].

\section{Effector cells of airway remodelling and EMT; contribution to potential endotypes of asthma}

Airway remodeling, in addition to inflammation, abnormal neurogenic and contractile response, has recently been appreciated as one of the contributors to the symptoms, abnormal physiology and natural history of asthma and therefore is likely to generate manifestation of the disorder as phenotype. This novel concept led to a series of studies delineating cellular and molecular mechanisms of airway remodeling and clinical trials aiming to identify subpopulations of asthmatics with similar disease mechanism (endotype) [64,65]. Airway remodeling is a collective term for structural alterations of airways encompassing the subepithelial fibrosis, myofibroblast hyperplasia and smooth muscle hypertrophy. The role of EMT in the development of subepthelial fibrosis, has been considered $[28,66]$ upon observation of elevated TGF $\beta 1$ production by eosinophils and fibroblasts in patients with severe and moderate asthma $[67,68]$. Studies of allergen-induced airway remodeling in transgenic mice suggested an important role of TGF $\beta 1$, VEGF, Th2 cytokines (IL-5, IL-4, IL-13), and epithelial derived NF$\mathrm{KB}$ regulated chemokines in airway remodeling, while eosinophils have received attention as cells contributing to thickening of reticular basal membrane [14]. Mechanistically, eosinophils are the source of potent cytotoxic mediators, such as leukotrienes, metalloproteinases, and growth factors, including TGF $\beta 1$ [69]. In patients with severe asthma, eosinophils constitute the majority of
TGF $\beta 1$ producing cells as bronchial biopsies showed that $65 \%$ of TGF $\beta 1 \mathrm{mRNA}$-positive cells are eosinophils and $75 \%$ of lung eosinophils were positive for TGF $\beta 1$ mRNA [70]. Animal studies of airway inflammation using interleukin- 5 and eotaxin-transgenic models indicate that goblet cell hyperplasia, epithelial hypertrophy, and focal collagen deposition are eosinophil-dependent [71,72]. Complementing these observations, $\triangle$ dblGATA eosinophil-deficient and IL-5-deficient mice showed significant reduction in subepithelial collagen deposition and smooth muscle proliferation upon single challenge or chronic exposure to allergen [56,73]. Furthermore, allergen challenge experiments in IL-5-deficient mouse showed decreased numbers of TGF $\beta 1$-positive cells in the peribronchial region and reduced expression of TGF $\beta 1$ in the whole lung [57]. The role of eosinophils in mediating EMT was directly shown in experiments where intratracheal instillation of bone marrow-derived eosinophils into mouse airways resulted in a marked deposition of type I collagen and significant fibrosis [74]. These changes were accompanied by decreased ECad and increased $\alpha$-SMA expression $21 \mathrm{~d}$ after eosinophil instillation. These findings complemented an earlier study employing anti-IL-5 antibody in patients with severe eosinophilic asthma refractory to corticosteroids that demonstrated that a reduction in eosinophils was associated with decreased basement membrane deposition of tenascin, lumican and procollagen type III [75].

However, there are several observations suggesting that airway remodeling in asthma may occur without significant involvement of eosinophils [76] or even in the absence of inflammation. For example, repeated methacholine-induced bronchoconstriction in mild atopic asthmatics resulted in airway remodeling comparable to that of induced by allergen challenge [77]. This remodeling was accompanied by increased expression of TGF $\beta 1$ in the bronchial epithelium without airway eosinophilia suggesting heterogeneous upstream mechanisms mediate airway remodeling. Besides eosinophils, macrophages of alternative phenotype (known as the "M2 type") were shown to participate in lung fibrotic processes in experimental models of nematode infection in IL-4R deficient mice [78,79]. Macrophage polarization toward the M2 phenotype is characterized by increased expression and secretion of TGF $\beta 1$ and can be achieved by stimulation of macrophages with IL-4, IL-13 [80] and glucocorticoids [81]. Although the ability of M2 macrophages to produce TGF $\beta 1$ upon stimulation of cytokines overexpressed in asthmatic airways implied their involvement in fibrotic and remodeling processes in asthma, recent observations have, however, shown overlapping of M1/M2 phenotypes and conversion of one phenotype to another depending upon the inflammatory response [82]. Similarly to macrophages, bronchial smooth muscle cells and 
dendritic cells were considered to play role airway remodeling after observation of enhanced secretion of TGF $\beta 1$ in response to neutrophil-derived elastase $[83,84]$. Since neutrophils infiltrate airways in severe and chronic asthma, their ability to mediate production of TGF $\beta 1$ may affect airway remodeling seen in this group of patients [85].

The correlation of airway remodeling with features of EMT, expression of TGF $\beta 1$, severity of disease, resistance to glucocorticoid therapy and airway eosinophilia or neutrophilia can be used to define distinct molecular phenotypes of asthma and to some degree asthma endotype. The asthma "phenotype" is the result of a complex constellation of pathophysiological processes, whereas an "endotype" represents a subtype of disease defined functionally and pathologically by a singular molecular mechanism translating into a treatment response $[86,87]$. Although no single endotype of asthma has yet been fully characterized, several potential endotypes were proposed based on clinical characteristics, biomarkers, histology and treatment response. In this regard, the phenotype of steroid-refractory asthma may include the potential endotype of steroid-insensitive eosinophilic asthma, a relatively rare form of asthma with airway eosinophilia, histological features of airway remodeling, glucocorticoid resistance and sensitivity to anti-IL-5 treatment [86]. This endotype mechanistically resembles IL-5 transgenic or IL-5 deficient mouse models [75].

Future research exploring the role of EMT in airway remodeling may delineate that EMT may play a role common to several endotypes. For example, EMT may contribute to steroid insensitivity as suggested by decreased induction of anti-inflammatory genes by glucocorticoids in TGF $\beta 1$-EMT transformed cells A549 cells [88]. In neutrophilic asthma, another subtype of severe steroid refractory asthma characterized by Th17mediated neutrophilic inflammation and the absence of airway eosinophilia, airway remodeling may result from EMT induced by TGF $\beta 1$ released from elastasestimulated bronchial smooth muscle cells and/or dendritic cells [85]. Furthermore, even the endotype of Th2-high, early-onset asthma with high eosinophilia and good response to steroid treatment exhibits some features of airway remodeling [89] as shown by thickening of reticular basement membrane by median age of 29 months in preschoolers with recurrent wheezing [90]. Although not yet defined, this endotype, driven by IL-4 and IL-13, may feature a role of TGF $\beta 1$ released from M2 polarized macrophages or from macrophages activated during phagocytosis of apoptotic eosinophils. Similarly, the severe, late-onset eosinophilic asthma endotype, representing $20 \%$ of the severe asthma population [91], also shows features of TGF $\beta 1$ mediated EMT and airway remodeling in spite of good response to systemic corticosteroid therapy.
In conclusion, future studies aiming at defining asthma endotypes should consider identification of mechanisms and respective biomarkers of TGF $\beta 1$ mediated EMT. Search for specific endotype biomarkers must focus on homogenous group of patients according to underlying disease mechanisms described by histological features (e.g. eosinophilia, M2 polarized macrophages), cytokine signatures (e.g. TGF $\beta 1$, IL4, IL-5) and responsiveness to anti-cytokine and glucocorticoid therapy. Systemic studies need to be directed at the cellular, molecular, and genetic factors that are responsible for determining why only some asthmatics develop significant remodeling. The information gathered from these studies will impact strategies employed to combat this increasingly complex and heterogeneous disorder.

\section{Effects of EMT on epithelial innate signaling responses}

In addition to affecting glucocorticoid response discussed above, changes in the phenotype of epithelial cells in asthma may determine effects on innate signaling responses [20]. Our earlier systems-level study observed that EMT had dramatic effects on the induction of the innate NF- $\mathrm{kB}$ pathway by producing an exaggerated inflammatory response and by reducing the coupling interval between the rapid canonical response and the slower noncanonical pathway. Previous work has shown that type III EMT is associated with epigenetic modifications on specific genetic loci, including induction of the euchromatin mark H3-lys4 trimethylation, or the transcriptional mark H3K36 trimethylation [20,92]. Our studies in primary human airway cells indicated that enhanced responsiveness of the NF-kB pathway is mediated by accumulation of H3K4 trimethylation marks in NF-kB-dependent genes working in concert with transcriptional elongation [20]. Transcriptional elongation is a characteristic gene control mechanism of innate response genes mediated by the cyclin-dependent kinase (CDK9). Our findings indicate that EMT induces genetic reprogramming of innate response genes through repositioning of activated histone transcriptional marks and through modification of CDK activity (schematically diagrammed in Figure 3). As a result, the dynamic inflammatory response of the epithelial cell is fundamentally changed by the EMT state. However, the mechanism by which specific loci are targeted for chromatin modifications is still unclear.

Further systems level studies will help to understand the complexity of the epigenetic reprogramming with the inducible phenotype produced by EMT. These approaches include mathematical modeling of signaling pathways to infer how EMT influences dynamic responses, systematic phosphoprotein profiling in response to cellular stimulation to identify coupling of intracellular signaling pathways and 


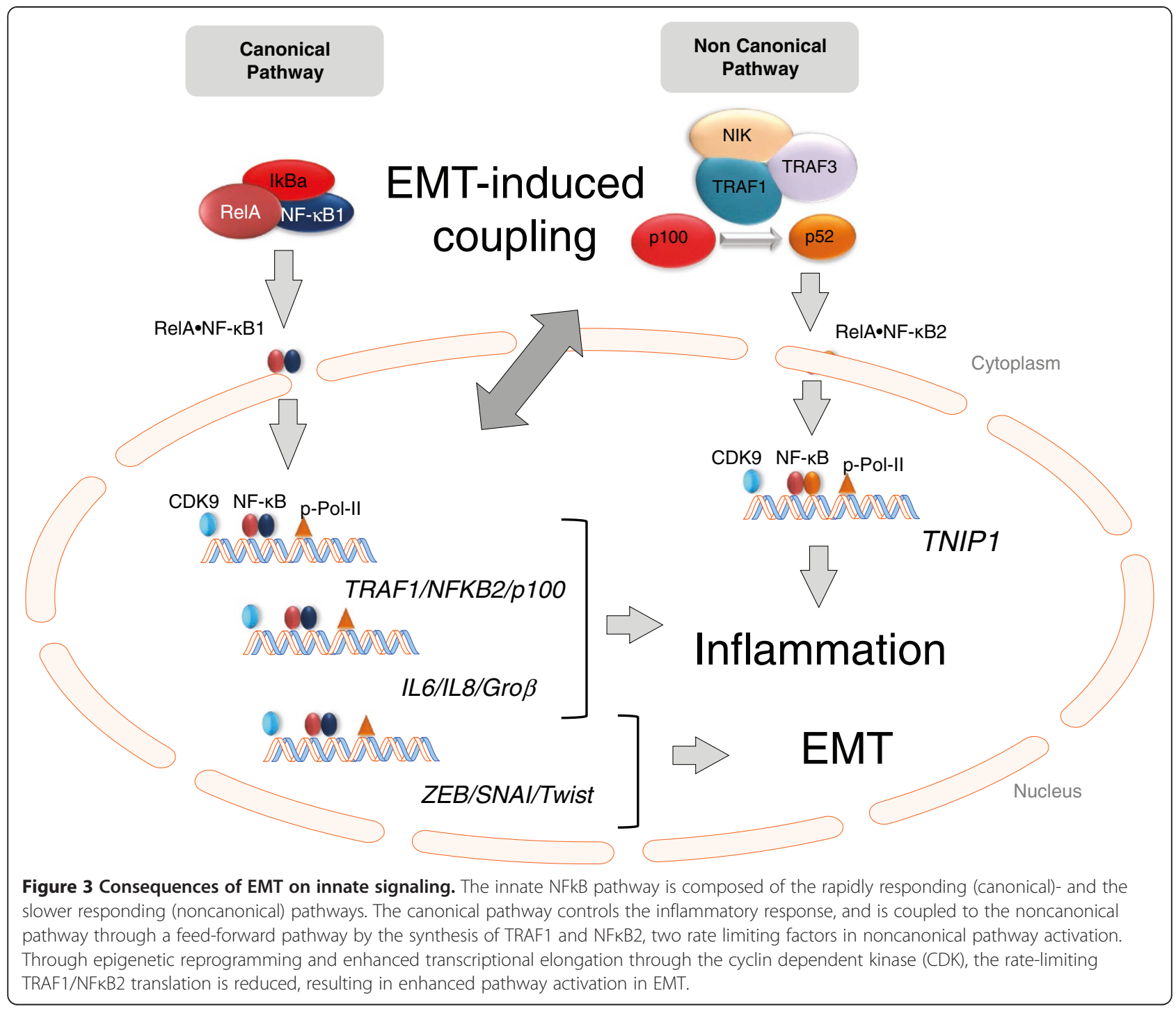

computational prediction of transcription factor binding sites at a genome-wide level. Application of this latter methodology has identified motifs that likely regulate dynamics of Polycomb-mediated histone modifications during murine stem cell differentiation [93]. Furthermore, whole genome studies have shown H3K36me3 is a specific epigenetic signature that modulates selection of exon-intron junctions, thereby allowing expression of mRNA splice variants characteristic of EMT [94,95].

\section{Effects of EMT on innate/adaptive immune cell signaling}

Severe asthma is associated with defects in innate immunity [4], including increased susceptibility to rhinovirus (RV) infections, leading to increased lower respiratory tract inflammation and hyper-reactivity. EMT-induced remodeling of the epithelial basement membrane promotes sensitization to inhaled allergen by causing persistent dendritic cell (DC) activation and migration [96]. Two studies have shown that sentinel respiratory cells replicate rhinovirus more efficiently and show deficient induction of type I/III IFNs, IFNs- $\beta$ and $-\lambda$, with impaired ability to induce apoptosis $[97,98]$. This defect in type III IFN production was highly correlated with severity of RV-induced asthma exacerbation and virus load in experimentally infected human volunteers, suggesting that asthmatics have an acquired defect in type III IFN production in sentinel cells of the airway. The contributions of EMT in modulating the innate and adaptive immune responses, such as IFN- $\gamma$ and TGF- $\beta$ production, require further exploration.

Although the effect of type II EMT on innate and adaptive immunity in the airway is incompletely delineated, the understanding of type III EMT on adaptive immunity has been extensively investigated. Epigenetic modifications induced in type III EMT suppress transcription of the NK cell activating receptor, NKG2D 
[99], secretion of soluble decoy ligands MICA/B [100] or by localized cell-surface expression of NKG2D ligands [101]. SNAI1, the EMT master regulator, promotes immunosuppression by inducing differentiation of immature DCs into regulatory DCs with low MHC class II expression and associated costimulatory molecules and prevents NKG2D expression in NK cells [102], thus suppressing the innate immune response. Tumor cells also acquire resistance to lysis by antigen-specific CTLs following EMT by induction of autophagy through Beclin 1 [103]. Even though there is overlap between type II and type III EMT signaling and EMT's effect on immunity, more work is required to determine which features of EMT are shared by the two EMT programs and to understand the role of EMT in modifying the innate immune response, autophagy and immunoediting in asthma.

\section{Systems level studies of the EMT phenotype}

Discussed above, the complex events produced by transcriptional reprogramming and global epigenetic rearrangement by EMT fundamentally change the inducible phenotype of the airway epithelial cell. To better understand the various asthma phenotypes, systems level studies of EMT are needed. Systems biology is an iterative process that involves the application of high throughput measurements to cellular perturbations. These data are used to develop predictive models that drive subsequent rounds of experimentation, perturbations, and predictive model refinement (Figure 4). Application of the systems biology approach can fundamentally contribute in-depth understanding of how signaling pathways and their interactions may be dysregulated by EMT (Figure 4).
A classic example of implemented framework of systems biology was the comprehensive study of the compiled gene expression data from five publicly available mouse microarray datasets and 4,305 gene annotation sets to provide the functional knowledge base [104]. A Module Networks analysis was used to identify coregulated gene modules, inferring four distinct responses to treatment, including early response, general induction, repression, and IL-13-dependent response to the treatment. Each module consists of potential set of genes in a pathway interaction map responsible for the corresponding effect. Among the novel observations include heterogeneity in the gene expression of genetically identical animals, a transcriptionally distinct module of known and potentially novel asthma genes.

High-throughput proteomics and metabolomics have helped to classify asthmatic patients by many proteins found in the airways, which can be used clinically as useful biomarkers [105,106]. Saha et al. compiled the asthma biomarkers from genomics, proteomics, epigenetics and few experimentally validated datasets, and derived significant enrichment of pathways, including adipokine and ROS pathways [107]. Similarly, gene profiling studies on cancer-related type III EMT have shown that TGF $\beta$ induces global changes in mRNA expression, mRNA splicing [108] and microRNA expression [109]. Parallel proteomics studies have demonstrated that type III EMT induces growth factor independence pathways downstream of IL-6 signaling [110], which has led to a better understanding of cellular and signaling processes involved in cancer metastases [111,112].

A recent study focused on the consequences of EMT to pro-survival signaling using a correlation analysis of

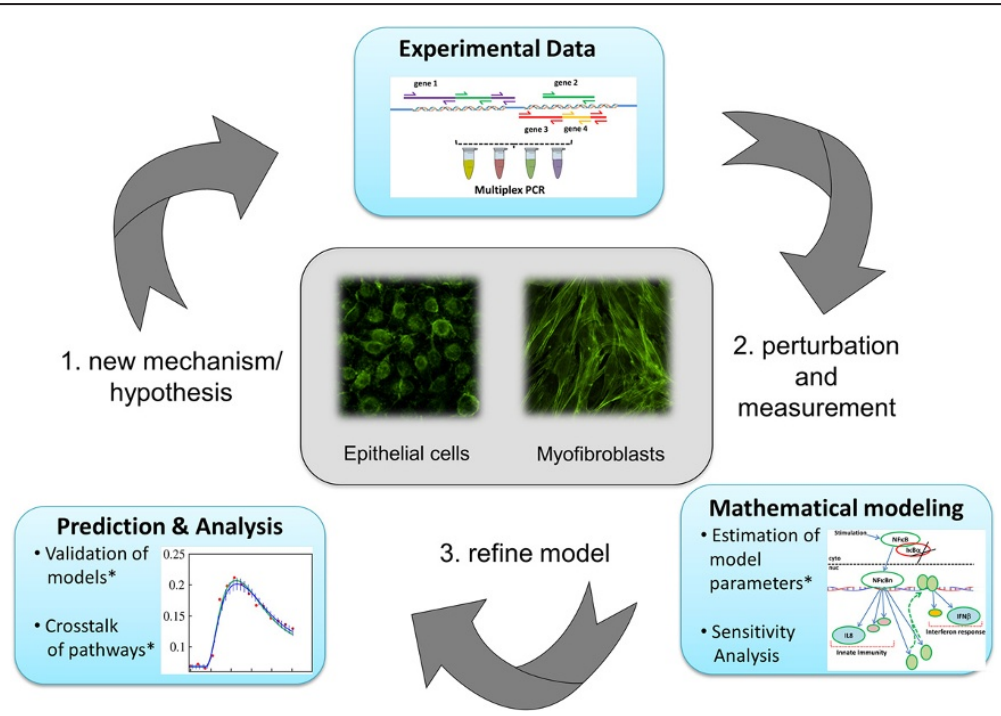

Figure 4 Systems approaches to EMT. Systems biology is an iterative process of high throughput measurement in response to perturbations, leading to refinement of predictive mathematical models, developing new mechanisms and subsequent rounds of testing. 
global measurements of protein, phosphoprotein and RNA transcript abundance [110]. These measurements were used to quantitate the differences in signaling dynamics between three different states of EMT: pre- or potential-EMT state, a reversible 'metastable' EMT state and an 'epigenetically-fixed' EMT state. The crosscorrelation strategy showed differential abundance amongst multiple EMT models (218 proteins, 146 phosphoproteins and nearly 1200 RNA transcripts). A functional clustering analysis further identified significantly enriched yet differentially regulated networks between epithelial and mesenchymal states. A number of marked changes in cell-cell junctional proteins involved in cell polarity, desmosomal junctions and adhesion to basement membrane were observed with EMT. There were also substantial changes in autocrine networks (EGFR, Met and IGIFR family) and metabolic networks (redoxstress, glycolytic and oxidative pathways) with EMT. A gain of six networks with EMT including IL-11 and IL-6 mediated gp130-JAK activation was also measured. A set of EMT transcription nodes were also identified suggesting that observed differences in phenotypes could be correlated with specific transcription components, one being NF-кB2/RelA. Carefully designed systems approach revealed significant differences between epithelial and mesenchymal signaling states, thus providing new avenues for drug discovery research for modulating type III EMT. Interestingly, a genome wide profiling of chromatin signatures in human genome showed that active promoters are marked by histone- 3 lysine-trimethylation whereas enhancers are marked by monomethylation [113]. Similar distinct signatures may be present and may be a predictive tool between "metastable" and "epigenetically-fixed" EMT states.

By contrast, fewer systems level studies have been applied to understand type II EMT. Although there are likely to be some important commonalities between types II and -III EMT, type II EMT is qualitatively different process because EMT of primary epithelial cells is not produced in the milieu of p53 mutation, activation of Wnt/ $\beta$ catenin or constitutive activation of $\mathrm{NF \kappa B}$ pathways, pathways that modulate EMT. To better understand the effects of type II EMT on innate signaling, we have applied systems level studies of type II EMT using innate perturbations. Time-course perturbation experiments were used to develop parameters of mathematical models of the innate pathway [20]. Computational simulations predicted that a cap-independent translational mechanism of the rate-limiting TRAF-1and NF- $\mathrm{kB} 2$ proteins was responsible for reducing the noncanonical pathway coupling interval observed experimentally. These predictions were confirmed experimentally using inhibitors of cap-independent translation [20]. In this way, application of systems modeling and perturbations provided novel insight into how the complex transcriptional reprogramming events of EMT influence dynamic response of the innate pathway.

Further applications of systems approaches will provide comprehensive understanding of this complex phenotype through deterministic modeling and multidimensional genomic and proteomic profiling (Figure 4). This kind of integrative approach can potentially provide information about cytokines and growth factors that interact to promote EMT through changes in chromatin remodeling (histone modifications, methylation), posttranslational modifications (phosphoproteomics) and pathway crosstalk. Mathematical modeling of protein interactions discovered from different "omics" representing various pathways in asthma have been used to predict possible drug target genes [114]. Upon integrating data from various platforms and multiscale information from molecular to organ level, the usefulness of mathematical modeling has previously been demonstrated $[115,116]$. These studies provide new insights and predictions about treatment, response behavior and time, new drug formulations and optimization in a coherent manner. In addition to understanding the pathophysiology of asthma, the systems biology approach will also allow the process of developing new therapies, which will be more specific and cost-effective and yet, customized to patients phenotypes, thus expediting the clinical trials. An excellent example is the development of a novel approach for diagnosis of chronic obstructive pulmonary disease by coupling systems biology with label-free high-throughput detection [117]. Similar to the integrated proteomic studies of type III EMT discussed above, it would be interesting to see whether systems approaches can identify transcription nodes that govern type II EMT. Application of predictive biology will inform strategies for how to reprogram EMT state in complex organisms. Increasing our understanding of the role of EMT in asthma by systems biology will help us find and test personalized treatment options based upon particular characteristics of the disease phenotype.

\section{Translational implications}

EMT is a complex, dynamic epigenetic reprogramming event that plays a homeostatic role in airway response to injury. Left unchecked, EMT contributes to pathophysiology of severe asthma. Understanding how to reverse EMT has significant translational implications. For example, EMT affects the response to glucocorticoids and inflammatory cytokines in epithelial progenitor cells, an effect that probably plays a significant pathophysiological component in a number of asthma phenotypes. It is possible that reversal of the EMT phenotype may promote allergen tolerance, enable anti-inflammatory treatment response, reduce viral-induced exacerbations, and reverse of sub-epithelial fibrosis in 
patients with severe asthma. The targets for reversing EMT are only beginning to be defined, and could involve targeting modulatory TGF $\beta$ signaling pathways or epigenetic modifiers. A recent investigation into possible regulators of airway remodeling found that inhibition of aldose reductase prevents TGF $\beta 1$-induced activation of the PI3K/AKT/ GSK3 $\beta$ signaling pathways in a Smad-independent manner [115]. A separate investigation into the effects of the plantderived propolis on TGF $\beta 1$-induced signaling pathways and EMT in alveolar epithelial cells demonstrated that this compound prevents TGF $\beta 1$-induced cellular changes, suppressed activation of Smad2 and AKT signaling pathways and may be an inhibitor of airway remodeling [116]. The central role of histone modifications and cyclin dependent kinases in EMT [20] are also worthy of further exploration.

\section{Summary}

A hallmark of early asthma is the presence of epithelial injury/repair and expansion of subepithelial fibrosis. In the setting of chronic TGF $\beta$ stimulation from innate eosinophils and other leukocytes, modulated by ECM, epithelial cells undergo dramatic cellular transition known as type II EMT. Accumulating evidence from in vitro, animal and human studies suggest that chronic and refractory asthma is associated with type II EMT. EMT induces loss of mucosal barrier function, acquisition of mesenchymal characteristics and enhanced motility, and secretion of fibrotic proteins accounting for the remodeling phenotype of this disease. Here we review the evidence for EMT in producing defects in inducible phenotype of the epithelial cells including alterations in signal response characteristics of the innate response of the airways. Applications of systems level studies will be needed to unravel the dynamic and cross-talk signaling mechanisms characteristic of EMT. These exciting studies suggest that modulation of EMT may have therapeutic implications for reversing airway remodeling, restoring glucocorticoid response, and/or the innate immune defect observed in severe asthma.

\section{Abbreviations \\ ECad: E cadherin; ECM: Extracellular matrix; ECP: Eosinophilic cationic protein; EGF: Epithelial growth factor; EMT: Epithelial mesenchymal transition; EMU: Epithelial mesenchymal unit; FGF: Fibroblast growth factor; MUC: Mucin genes; NF-kB: Nuclear factor-kB; RV: Rhinovirus; SMA: Smooth muscle actin; SNAI: Snail; TGFB: Transforming growth factor $\beta$; Th: T helper cell type; VIM: Vimentin.}

\section{Competing interests}

The authors declare that they have no competing interests.

\section{Authors' contributions}

All authors contributed to literature review, writing the manuscript and editing the figures. All authors have read and approved the final manuscript.

\section{Acknowledgements}

This work was supported, in part, by the Sealy Center for Molecular Medicine, National Institute of Health grants PO1 Al062885 (ARB, IB), NHLBI contract HHSN268201000037C (ARB, IB, KP), UL1TR00007, Clinical and Translational Science Award (ARB) and NIEHS P30 ES006676.

\section{Author details}

'Department of Biochemistry and Molecular Biology, The University of Texas Medical Branch, 301 University Blvd, Galveston 77555-1060, Texas, USA. ${ }^{2}$ Sealy Center for Molecular Medicine, The University of Texas Medical Branch, 301 University Blvd, Galveston 77555-1060, Texas, USA. ${ }^{3}$ Institute for Translational Sciences, The University of Texas Medical Branch, 301 University Blvd, Galveston 77555-1060, Texas, USA. ${ }^{4}$ Department of Internal Medicine, The University of Texas Medical Branch, 301 University Blvd, Galveston 77555-1060, Texas, USA. ${ }^{5}$ Department of Microbiology and Immunology, The University of Texas Medical Branch, 301 University Blvd, Galveston

77555-1060, Texas, USA.

Received: 18 October 2013 Accepted: 16 May 2014

Published: 2 June 2014

\section{References}

1. Akinbami LJ, Moorman JE, Bailey C, Zahran HS, King M, Johnson CA, Liu X: Trends in asthma prevalence, health care use, and mortality in the United States, 2001-2010. NCHS Data Brief 2012, 94:1-8.

2. Anderson GP: Endotyping asthma: new insights into key pathogenic mechanisms in a complex, heterogeneous disease. Lancet 2008, 372:1107-1119.

3. Busse WW, Lemanske RF Jr: Asthma. N Engl J Med 2001, 344:350-362.

4. Moore WC, Bleecker ER, Curran-Everett D, Erzurum SC, Ameredes BT, Bacharier L, Calhoun WJ, Castro M, Chung KF, Clark MP, Dweik RA, Fitzpatrick AM, Gaston B, Hew M, Hussain I, Jarjour NN, Israel E, Levy BD, Murphy JR, Peters SP, Teague WG, Meyers DA, Busse WW, Wenzel SE: Characterization of the severe asthma phenotype by the national heart, lung, and blood institute's severe asthma research program. J Allergy Clin Immunol 2007, 119:405-413.

5. Auffray C, Adcock IM, Chung KF, Djukanovic R, Pison C, Sterk PJ: An integrative systems biology approach to understanding pulmonary diseases. Chest 2010, 137:1410-1416.

6. Kauffmann F, Demenais F: Gene-environment interactions in asthma and allergic diseases: challenges and perspectives. J Allergy Clin Immunol 2012, 130:1229-1240. quiz 1241-1222.

7. Toscano W, Oehlke K, Kafoury R: An environmental systems biology approach to the study of asthma. In Allergy Frontiers: Future Perspectives. 6th edition. Edited by Pawankar R, Holgate S, Rosenwasser L. Japan: Springer; 2010:239-252. Allergy Frontiers.

8. Knight $D$, Holgate $S T$ : The airway epithelium: structural and functional properties in health and disease. Respirology 2010, 8:432-446.

9. Lambrecht BN, Hammad H: The airway epithelium in asthma. Nat Med 2012, 18:684-692.

10. Brasier AR: Identification of innate immune response endotypes in asthma: implications for personalized medicine. Curr Allergy Asthma Rep 2013, 13:462-468.

11. Constant SL, Brogdon JL, Piggott DA, Herrick CA, Visintin I, Ruddle NH, Bottomly $K$ : Resident lung antigen-presenting cells have the capacity to promote Th2 T cell differentiation in situ. J Clin Invest 2002, 110:1441-1448.

12. Kim KK, Kugler MC, Wolters PJ, Robillard L, Galvez MG, Brumwell AN, Sheppard D, Chapman HA: Alveolar epithelial cell mesenchymal transition develops in vivo during pulmonary fibrosis and is regulated by the extracellular matrix. Proc Natl Acad Sci U S A 2006, 103:13180-13185.

13. Holgate ST, Holloway J, Wilson S, Bucchieri F, Puddicombe S, Davies DE: Epithelial-mesenchymal communication in the pathogenesis of chronic asthma. Proc Am Thorac Soc 2004, 1:93-98.

14. Holgate ST, Davies DE, Lackie PM, Wilson SJ, Puddicombe SM, Lordan JL: Epithelial-mesenchymal interactions in the pathogenesis of asthma. J Allergy Clin Immunol 2000, 105:193-204.

15. Kalluri R, Weinberg RA: The basics of epithelial-mesenchymal transition. J Clin Invest 2009, 119:1420-1428.

16. Zhou G, Dada LA, Wu M, Kelly A, Trejo H, Zhou Q, Varga J, Sznajder J: Hypoxia-induced alveolar epithelial-mesenchymal transition requires mitochondrial ROS and hypoxia-inducible factor 1. Am J Physiol Lung Cell Mol Physiol 2009, 297:L1120-L1130.

17. Manotham K, Tanaka T, Matsumoto M, Ohse T, Inagi R, Miyata T, Kurokawa K, Fujita T, Ingelfinger JR, Nangaku M: Transdifferentiation of cultured tubular cells induced by hypoxia. Kidney Int 2004, 65:871-880. 
18. Rhyu DY, Yang Y, Ha H, Lee GT, Song JS, Uh ST, Lee HB: Role of reactive oxygen species in TGF-beta1-induced mitogen-activated protein kinase activation and epithelial-mesenchymal transition in renal tubular epithelial cells. J Am Soc Nephrol 2005, 16:667-675.

19. Zavadil J, Böttinger EP: TGF-beta and epithelial-to-mesenchymal transitions. Oncogene 2005, 24:5764-5774.

20. Kalita M, Tian B, Gao B, Choudhary S, Wood TG, Carmical JR, Boldogh I, Mitra S, Minna JD, Brasier AR: Systems approaches to modeling chronic mucosal inflammation. BioMed Res Int 2013, in press.

21. Zeisberg M, Yang C, Martino M, Duncan MB, Rieder F, Tanjore H, Kalluri R: Fibroblasts derive from hepatocytes in liver fibrosis via epithelial to mesenchymal transition. J Biol Chem 2007, 282:23337-23347.

22. Zeisberg M, Hanai J, Sugimoto H, Mammoto T, Charytan D, Strutz F, Kalluri R: BMP-7 counteracts TGF-beta1-induced epithelial-to-mesenchymal transition and reverses chronic renal injury. Nat Med 2003, 9:964-968.

23. de Boer WI, Sharma HS, Baelemans SMI, Hoogsteden HC, Lambrecht BN, Braunstahl GJ: Altered expression of epithelial junctional proteins in atopic asthma: possible role in inflammation. Can J Physiol Pharmacol 2008, 86:105-112.

24. Sagara H, Okada T, Okumura K, Ogawa H, Ra C, Fukuda T, Nakao A: Activation of TGF-beta/Smad2 signaling is associated with airway remodeling in asthma. J Allergy Clin Immunol 2002, 110:249-254.

25. Kokturk N, Tatlicioglu T, Memis L, Akyurek N, Akyol G: Expression of transforming growth factor beta1 in bronchial biopsies in asthma and COPD. J Asthma 2003, 40:887-893.

26. Vignola AM, Chanez P, Chiappara G, Merendino A, Pace E, Rizzo A, la Rocca AM, Bellia V, Bonsignore G, Bousquet J: Transforming growth factor-beta expression in mucosal biopsies in asthma and chronic bronchitis. Am J Respir Crit Care Med 1997, 156:591-599.

27. Holgate ST, Arshad HS, Roberts GC, Howarth PH, Thurner P, Davies DE: A new look at the pathogenesis of asthma. Clin Sci 2010, 118:439-450.

28. Hackett TL, Warner SM, Stefanowicz D, Shaheen F, Pechkovsky DV, Murray LA, Argentieri R, Kicic A, Stick SM, Bai TR, Knight DA: Induction of epithelialmesenchymal transition in primary airway epithelial cells from patients with asthma by transforming growth factor-beta1. Am J Respir Crit Care Med 2009, 180:122-133.

29. Lee CG, Cho SJ, Kang MJ, Chapoval SP, Lee PJ, Noble PW, Yehualaeshet T, Lu B, Flavell RA, Milbrandt J, Homer RJ, Elias JA: Early growth response gene 1-mediated apoptosis is essential for transforming growth factor beta1-induced pulmonary fibrosis. J Exp Med 2004, 200:377-389.

30. McMillan SJ, Xanthou G, Lloyd CM: Manipulation of allergen-induced airway remodeling by treatment with anti-TGF-beta antibody: effect on the Smad signaling pathway. J Immunol 2005, 174:5774-5780.

31. Alcorn JF, Rinaldi LM, Jaffe EF, van Loon M, Bates JH, Janssen-Heininger YM, Irvin CG: Transforming growth factor-beta1 suppresses airway hyperresponsiveness in allergic airway disease. Am J Respir Crit Care Med 2007, 176:974-982.

32. Yamaguchi M, Niimi A, Matsumoto $H$, Ueda T, Takemura M, Matsuoka $H$, Jinnai M, Otsuka K, Oguma T, Takeda T, Ito I, Chin K, Mishima M: Sputum levels of transforming growth factor-beta1 in asthma: relation to clinical and computed tomography findings. J Investig Allergol Clin Immunol 2008, 18:202-206

33. Boxall C, Holgate ST, Davies DE: The contribution of transforming growth factor-beta and epidermal growth factor signalling to airway remodelling in chronic asthma. Eur Respir J 2006, 27:208-229.

34. Willis BC, Borok Z: TGF-beta-induced EMT: mechanisms and implications for fibrotic lung disease. Am J Physiol Lung Cell Mol Physiol 2007, 293:L525-L534.

35. Moir LM, Burgess JK, Black JL: Transforming growth factor beta 1 increases fibronectin deposition through integrin receptor alpha 5 beta 1 on human airway smooth muscle. J Allergy Clin Immunol 2008, 121:1034-1039. e1034.

36. Hocevar BA, Brown TL, Howe PH: TGF-beta induces fibronectin synthesis through a c-Jun N-terminal kinase-dependent, Smad4-independent pathway. EMBO J 1999, 18:1345-1356.

37. Buonato JM, Lazzara MJ: ERK1/2 blockade prevents epithelial-mesenchymal transition in lung cancer cells and promotes their sensitivity to EGFR inhibition. Cancer Res 2014, 74:309-319.

38. Xi Y, Tan K, Brumwell AN, Chen SC, Kim YH, Kim TJ, Wei Y, Chapman HA: Inhibition of epithelial-to-mesenchymal transition and pulmonary fibrosis by methacycline. Am J Respir Cell Mol Biol 2014, 50:51-60.
39. Zhou B, Liu Y, Kahn M, Ann DK, Han A, Wang H, Nguyen C, Flodby P, Zhong Q, Krishnaveni MS, Liebler JM, Minoo P, Crandall ED, Borok Z: Interactions between beta-catenin and transforming growth factor-beta signaling pathways mediate epithelial-mesenchymal transition and are dependent on the transcriptional co-activator cAMP-response element-binding protein (CREB)-binding protein (CBP). J Biol Chem 2012, 287:7026-7038.

40. Katsuno Y, Lamouille S, Derynck R: TGF-beta signaling and epithelialmesenchymal transition in cancer progression. Curr Opin Oncol 2013, 25:76-84.

41. Vincent T, Neve EP, Johnson JR, Kukalev A, Rojo F, Albanell J, Pietras K, Virtanen I, Philipson L, Leopold PL, Crystal RG, de Herreros AG, Moustakas A, Pettersson RF, Fuxe J: A SNAIL1-SMAD3/4 transcriptional repressor complex promotes TGF-beta mediated epithelial-mesenchymal transition. Nat Cell Biol 2009, 11:943-950.

42. Bracken CP, Gregory PA, Kolesnikoff N, Bert AG, Wang J, Shannon MF, Goodall GJ: A double-negative feedback loop between ZEB1-SIP1 and the microRNA-200 family regulates epithelial-mesenchymal transition. Cancer Res 2008, 68:7846-7854.

43. Kasai H, Allen JT, Mason RM, Kamimura T, Zhang Z: TGF-beta1 induces human alveolar epithelial to mesenchymal cell transition (EMT). Respir Res 2005, 6:56.

44. Camara J, Jarai G: Epithelial-mesenchymal transition in primary human bronchial epithelial cells is Smad-dependent and enhanced by fibronectin and TNF-alpha. Fibrogenesis Tissue Repair 2010, 3:2.

45. Doerner AM, Zuraw BL: TGF-beta1 induced epithelial to mesenchymal transition (EMT) in human bronchial epithelial cells is enhanced by IL-1beta but not abrogated by corticosteroids. Respir Res 2009, 10:100.

46. Barnes PJ, Karin M: Nuclear factor-kappaB: a pivotal transcription factor in chronic inflammatory diseases. [Review] [53 refs]. N Engl J Med 1997, 336:1066-1071.

47. Yang J, Mitra A, Dojer N, Fu S, Rowicka M, Brasier AR: A probabilistic approach to learn chromatin architecture and accurate inference of the NF-kappaB/RelA regulatory network using ChIP-Seq. Nucleic Acids Res 2013, 41:7240-7259.

48. Tian B, Nowak DE, Jamaluddin M, Wang S, Brasier AR: Identification of direct genomic targets downstream of the nuclear factor-\{kappa\}B transcription factor mediating tumor necrosis factor signaling. J Biol Chem 2005, 280:17435-17448.

49. Kim HJ, Litzenburger BC, Cui X, Delgado DA, Grabiner BC, Lin X, Lewis MT, Gottardis MM, Wong TW, Attar RM, Carboni JM, Lee AV: Constitutively active type I insulin-like growth factor receptor causes transformation and xenograft growth of immortalized mammary epithelial cells and is accompanied by an epithelial-to-mesenchymal transition mediated by NF-kappaB and snail. Mol Cell Biol 2007, 27:3165-3175.

50. Li CW, Xia W, Huo L, Lim SO, Wu Y, Hsu JL, Chao CH, Yamaguchi H, Yang NK, Ding Q, Wang Y, Lai YJ, LaBaff AM, Wu TJ, Lin BR, Yang MH, Hortobagyi GN, Hung MC: Epithelial-mesenchymal transition induced by TNF-alpha requires NF-kappaB-mediated transcriptional upregulation of Twist1. Cancer Res 2012, 72:1290-1300.

51. Wu Y, Deng J, Rychahou PG, Qiu S, Evers BM, Zhou BP: Stabilization of snail by NF-kappaB is required for inflammation-induced cell migration and invasion. Cancer Cell 2009, 15:416-428.

52. Doherty TA, Soroosh $P$, Khorram N, Fukuyama S, Rosenthal $P$, Cho JY, Norris PS, Choi H, Scheu S, Pfeffer K, Zuraw BL, Ware CF, Broide DH, Croft M: The tumor necrosis factor family member LIGHT is a target for asthmatic airway remodeling. Nat Med 2011, 17:596-603.

53. Mikami Y, Yamauchi $Y$, Horie M, Kase M, Jo T, Takizawa H, Kohyama T, Nagase T: Tumor necrosis factor superfamily member LIGHT induces epithelial-mesenchymal transition in A549 human alveolar epithelial cells. Biochem Biophys Res Commun 2012, 428:451-457.

54. Aoyagi-Ikeda K, Maeno T, Matsui H, Ueno M, Hara K, Aoki Y, Aoki F, Shimizu T, Doi H, Kawai-Kowase K, Iso T, Suga T, Arai M, Kurabayashi M: Notch induces myofibroblast differentiation of alveolar epithelial cells via transforming growth factor-\{beta\}-Smad3 pathway. Am J Respir Cell Mol Biol 2011, 45:136-144.

55. Fulkerson PC, Fischetti CA, McBride ML, Hassman LM, Hogan SP, Rothenberg ME: A central regulatory role for eosinophils and the eotaxin/CCR3 axis in chronic experimental allergic airway inflammation. Proc Natl Acad Sci U S A 2006, 103:16418-16423.

56. Humbles AA, Lloyd CM, McMillan SJ, Friend DS, Xanthou G, McKenna EE, Ghiran S, Gerard NP, Yu C, Orkin SH, Gerard C: A critical role for eosinophils in allergic airways remodeling. Science 2004, 305:1776-1779. 
57. Cho JY, Miller M, Baek KJ, Han JW, Nayar J, Lee SY, McElwain K, McElwain S, Friedman S, Broide DH: Inhibition of airway remodeling in IL-5-deficient mice. J Clin Invest 2004, 113:551-560.

58. Halwani R, Al-Muhsen S, Al-Jahdali H, Hamid Q: Role of transforming growth factor-beta in airway remodeling in asthma. Am J Respir Cell Mol Biol 2011, 44:127-133.

59. Tawara I, Shlomchik WD, Jones A, Zou W, Nieves E, Liu C, Toubai T, Duran-Struuck R, Sun Y, Clouthier SG, Evers R, Lowler KP, Levy RB, Reddy P: A crucial role for host APCs in the induction of donor CD4 + CD25+ regulatory T cell-mediated suppression of experimental graft-versus-host disease. $\mathrm{J}$ Immunol 2010, 185:3866-3872.

60. Cox TR, Erler JT: Remodeling and homeostasis of the extracellular matrix: implications for fibrotic diseases and cancer. Dis Model Mech 2011, 4:165-178.

61. Kim KK, Wei Y, Szekeres C, Kugler MC, Wolters PJ, Hill ML, Frank JA, Brumwell AN, Wheeler SE, Kreidberg JA, Chapman HA: Epithelial cell alpha3beta1 integrin links beta-catenin and Smad signaling to promote myofibroblast formation and pulmonary fibrosis. J Clin Invest 2009, 119:213-224.

62. Heijink IH, Postma DS, Noordhoek JA, Broekema M, Kapus A: House dust mite-promoted epithelial-to-mesenchymal transition in human bronchial epithelium. Am J Respir Cell Mol Biol 2010, 42:69-79.

63. Kaltenborn E, Kern S, Frixel S, Fragnet L, Conzelmann KK, Zarbock R, Griese $M$ : Respiratory syncytial virus potentiates ABCA3 mutation-induced loss of lung epithelial cell differentiation. Hum Mol Genet 2012, 21:2793-2806.

64. Bousquet J, Jeffery PK, Busse WW, Johnson M, Vignola AM: Asthma. From bronchoconstriction to airways inflammation and remodeling. Am J Respir Crit Care Med 2000, 161:1720-1745.

65. James $A L$, Wenzel S: Clinical relevance of airway remodelling in airway diseases. Eur Respir J 2007, 30:134-155.

66. Hackett TL: Epithelial-mesenchymal transition in the pathophysiology of airway remodelling in asthma. Curr Opin Allergy Clin Immunol 2012, 12:53-59.

67. Chakir J, Shannon J, Molet S, Fukakusa M, Elias J, Laviolette M, Boulet LP, Hamid Q: Airway remodeling-associated mediators in moderate to severe asthma: effect of steroids on TGF-beta, IL-11, IL-17, and type I and type III collagen expression. J Allergy Clin Immunol 2003, 111:1293-1298.

68. Redington AE, Madden J, Frew AJ, Djukanovic R, Roche WR, Holgate ST, Howarth PH: Transforming growth factor-beta 1 in asthma. Measurement in bronchoalveolar lavage fluid. Am J Respir Crit Care Med 1997, 156:642-647.

69. Blanchard C, Rothenberg ME: Biology of the eosinophil. Adv Immunol 2009, 101:81-121.

70. Minshall EM, Leung DY, Martin RJ, Song YL, Cameron L, Ernst P, Hamid Q: Eosinophil-associated TGF-beta1 mRNA expression and airways fibrosis in bronchial asthma. Am J Respir Cell Mol Biol 1997, 17:326-333.

71. Ochkur SI, Jacobsen EA, Protheroe CA, Biechele TL, Pero RS, McGarry MP, Wang H, O'Neill KR, Colbert DC, Colby TV, Shen H, Blackburn MR, Irvin CC, Lee JJ, Lee NA: Coexpression of IL-5 and eotaxin-2 in mice creates an eosinophil-dependent model of respiratory inflammation with characteristics of severe asthma. J Immunol 2007, 178:7879-7889.

72. Tanaka H, Komai M, Nagao K, Ishizaki M, Kajiwara D, Takatsu K, Delespesse G, Nagai $\mathrm{H}$ : Role of interleukin-5 and eosinophils in allergen-induced airway remodeling in mice. Am J Respir Cell Mol Biol 2004, 31:62-68.

73. Cho JY, Pham A, Rosenthal P, Miller M, Doherty T, Broide DH: Chronic OVA allergen challenged TNF p55/p75 receptor deficient mice have reduced airway remodeling. Int Immunopharmacol 2011, 11:1038-1044.

74. Yasukawa A, Hosoki K, Toda M, Miyake Y, Matsushima Y, Matsumoto T, Boveda-Ruiz D, Gil-Bernabe P, Nagao M, Sugimoto M, Hiraguchi Y, Tokuda R, Naito M, Takagi T, D'Alessandro-Gabazza CN, Suga S, Kobayashi T, Fujisawa T, Taguchi O, Gabazza EC: Eosinophils promote epithelial to mesenchymal transition of bronchial epithelial cells. PLoS One 2013, 8:e64281.

75. Haldar P, Brightling CE, Hargadon B, Gupta S, Monteiro W, Sousa A, Marshall RP, Bradding P, Green RH, Wardlaw AJ, Pavord ID: Mepolizumab and exacerbations of refractory eosinophilic asthma. N Engl J Med 2009, 360:973-984.

76. Fattouh R, Al-Garawi A, Fattouh M, Arias K, Walker TD, Goncharova S, Coyle AJ, Humbles AA, Jordana M: Eosinophils are dispensable for allergic remodeling and immunity in a model of house dust mite-induced airway disease. Am J Respir Crit Care Med 2011, 183:179-188.

77. Grainge CL, Lau LC, Ward JA, Dulay V, Lahiff G, Wilson S, Holgate S, Davies $D E$, Howarth PH: Effect of bronchoconstriction on airway remodeling in asthma. N Engl J Med 2011, 364:2006-2015.
78. Loke P, Nair MG, Parkinson J, Guiliano D, Blaxter M, Allen JE: IL-4 dependent alternatively-activated macrophages have a distinctive in vivo gene expression phenotype. BMC Immunol 2002, 3:7.

79. Loke P, Gallagher I, Nair MG, Zang X, Brombacher F, Mohrs M, Allison JP, Allen JE: Alternative activation is an innate response to injury that requires $C D 4+T$ cells to be sustained during chronic infection. J Immunol 2007, 179:3926-3936.

80. Martinez FO, Helming L, Gordon S: Alternative activation of macrophages: an immunologic functional perspective. Annu Rev Immuno/ 2009, 27:451-483.

81. Gratchev A, Kzhyshkowska J, Utikal J, Goerdt S: Interleukin-4 and dexamethasone counterregulate extracellular matrix remodelling and phagocytosis in type-2 macrophages. Scand J Immunol 2005, 61:10-17.

82. Mosser DM, Edwards JP: Exploring the full spectrum of macrophage activation. Nat Rev Immunol 2008, 8:958-969.

83. Lee KY, Ho SC, Lin HC, Lin SM, Liu CY, Huang CD, Wang CH, Chung KF, Kuo HP: Neutrophil-derived elastase induces TGF-beta1 secretion in human airway smooth muscle via NF-kappaB pathway. Am J Respir Cell Mol Biol 2006, 35:407-414.

84. Maffia PC, Zittermann SE, Scimone ML, Tateosian N, Amiano N, Guerrieri D, Lutzky V, Rosso D, Romeo HE, Garcia VE, Issekutz AC, Chuluyan HE: Neutrophil elastase converts human immature dendritic cells into transforming growth factor-beta1-secreting cells and reduces allostimulatory ability. Am J Pathol 2007, 171:928-937.

85. Hoshino M, Nakamura Y, Sim J, Shimojo J, Isogai S: Bronchial subepithelial fibrosis and expression of matrix metalloproteinase- 9 in asthmatic airway inflammation. J Allergy Clin Immunol 1998, 102:783-788.

86. Lötvall J, Akdis CA, Bacharier LB, Bjermer L, Casale TB, Custovic A, Lemanske RF, Wardlaw AJ, Wenzel SE, Greenberger PA: Asthma endotypes: a new approach to classification of disease entities within the asthma syndrome. J Allergy Clin Immunol 2011, 127:355-360.

87. Wenzel S: Severe asthma: from characteristics to phenotypes to endotypes. Clin Exp Allergy 2012, 42:650-658.

88. Salem S, Harris T, Mok JS, Li MY, Keenan CR, Schuliga MJ, Stewart AG: Transforming growth factor- $\beta$ impairs glucocorticoid activity in the A549 lung adenocarcinoma cell line. Br J Pharmacol 2012, 166:2036-2048.

89. Woodruff PG, Modrek B, Choy DF, Jia G, Abbas AR, Ellwanger A, Koth LL, Arron JR, Fahy JV: T-helper type 2-driven inflammation defines major subphenotypes of asthma. Am J Respir Crit Care Med 2009, 180:388-395.

90. Saglani S, Payne DN, Zhu J, Wang Z, Nicholson AG, Bush A, Jeffery PK: Early detection of airway wall remodeling and eosinophilic inflammation in preschool wheezers. Am J Respir Crit Care Med 2007, 176:858-864.

91. Miranda C, Busacker A, Balzar S, Trudeau J, Wenzel SE: Distinguishing severe asthma phenotypes: role of age at onset and eosinophilic inflammation. J Allergy Clin Immunol 2004, 113:101-108.

92. McDonald OG, Wu H, Timp W, Doi A, Feinberg AP: Genome-scale epigenetic reprogramming during epithelial-to-mesenchymal transition. Nat Struct Mol Biol 2011, 18:867-874.

93. Arnold P, Schöler A, Pachkov M, Balwierz PJ, Jørgensen H, Stadler MB, van Nimwegen E, Schübeler D: Modeling of epigenome dynamics identifies transcription factors that mediate Polycomb targeting. Genome Res 2013, 23:60-73.

94. Schwartz S, Meshorer E, Ast G: Chromatin organization marks exon-intron structure. Nat Struct Mol Biol 2009, 16:990-995.

95. Kolasinska-Zwierz P, Down T, Latorre I, Liu T, Liu XS, Ahringer J: Differential chromatin marking of introns and expressed exons by H3K36me3. Nat Genet 2009, 41:376-381.

96. van Rijt LS, Vos N, Willart M, Muskens F, Tak PP, van der Horst C, Hoogsteden HC, Lambrecht BN: Persistent activation of dendritic cells after resolution of allergic airway inflammation breaks tolerance to inhaled allergens in mice. Am J Respir Crit Care Med 2011, 184:303-311.

97. Wark PA, Johnston SL, Bucchieri F, Powell R, Puddicombe S, Laza-Stanca V, Holgate ST, Davies DE: Asthmatic bronchial epithelial cells have a deficient innate immune response to infection with rhinovirus. J Exp Med 2005, 201:937-947.

98. Contoli M, Message SD, Laza-Stanca V, Edwards MR, Wark PA, Bartlett NW, Kebadze T, Mallia P, Stanciu LA, Parker HL, Slater L, Lewis-Antes A, Kon OM Holgate ST, Davies DE, Kotenko SV, Papi A, Johnston SL: Role of deficient type III interferon-lambda production in asthma exacerbations. Nat Med 2006, 12:1023-1026.

99. López-Soto A, Folgueras AR, Seto E, Gonzalez S: HDAC3 represses the expression of NKG2D ligands ULBPs in epithelial tumour cells: potential 
implications for the immunosurveillance of cancer. Oncogene 2009, 28:2370-2382.

100. Groh V, Wu J, Yee C, Spies T: Tumour-derived soluble MIC ligands impair expression of NKG2D and T-cell activation. Nature 2002, 419:734-738.

101. Oppenheim DE, Roberts SJ, Clarke SL, Filler R, Lewis JM, Tigelaar RE, Girardi M, Hayday AC: Sustained localized expression of ligand for the activating NKG2D receptor impairs natural cytotoxicity in vivo and reduces tumor immunosurveillance. Nat Immunol 2005, 6:928-937.

102. Della Chiesa M, Carlomagno S, Frumento G, Balsamo M, Cantoni C, Conte R, Moretta L, Moretta A, Vitale M: The tryptophan catabolite L-kynurenine inhibits the surface expression of NKp46- and NKG2D-activating receptors and regulates NK-cell function. Blood 2006, 108:4118-4125

103. Akalay I, Janji B, Hasmim M, Noman MZ, Thiery JP, Mami-Chouaib F, Chouaib S: EMT impairs breast carcinoma cell susceptibility to CTL-mediated lysis through autophagy induction. Autophagy 2013, 9:1104-1106.

104. Novershtern N, Itzhaki Z, Manor O, Friedman N, Kaminski N: A functional and regulatory map of asthma. Am J Respir Cell Mol Biol 2008, 38:324-336.

105. Fens N, Zwinderman AH, van der Schee MP, de Nijs SB, Dijkers E, Roldaan AC, Cheung D, Bel EH, Sterk PJ: Exhaled breath profiling enables discrimination of chronic obstructive pulmonary disease and asthma. Am J Respir Crit Care Med 2009, 180:1076-1082.

106. Brasier AR, Victor S, Boetticher G, Ju H, Lee C, Bleecker ER, Castro M, Busse WW, Calhoun WJ: Molecular phenotyping of severe asthma using pattern recognition of bronchoalveolar lavage-derived cytokines. J Allergy Clin Immunol 2008, 121:30-37. e36.

107. Sircar G, Saha B, Bhattacharya SG, Saha S: Allergic asthma biomarkers using systems approaches. Front Genetx 2014, 4:308.

108. Shapiro IM, Cheng AW, Flytzanis NC, Balsamo M, Condeelis JS, Oktay MH, Burge CB, Gertler FB: An EMT-driven alternative splicing program occurs in human breast cancer and modulates cellular phenotype. PLOS Genet 2011, 7:e1002218.

109. Mongroo PS, Rustgi AK: The role of the miR-200 family in epithelialmesenchymal transition. Cancer Biol Ther 2010, 10:219-222.

110. Thomson S, Petti F, Sujka-Kwok I, Mercado P, Bean J, Monaghan M, Seymour SL, Argast GM, Epstein DM, Haley JD: A systems view of epithelialmesenchymal transition signaling states. Clin Exp Metastasis 2011, 28:137-155.

111. Yang J, Eddy JA, Pan Y, Hategan A, Tabus I, Wang Y, Cogdell D, Price ND, Pollock RE, Lazar AJ, Hunt KK, Trent JC, Zhang W: Integrated proteomics and genomics analysis reveals a novel mesenchymal to epithelial reverting transition in leiomyosarcoma through regulation of slug. Mol Cell Proteomics 2010, 9:2405-2413.

112. Hanash S, Schliekelman M, Zhang Q, Taguchi A: Integration of proteomics into systems biology of cancer. Wiley Interdiscip Rev Syst Biol Med 2012, 4:327-337.

113. Heintzman ND, Stuart RK, Hon G, Fu Y, Ching CW, Hawkins RD, Barrera LO, Van Calcar S, Qu C, Ching KA, Wang W, Weng Z, Green RD, Crawford GE, Ren B: Distinct and predictive chromatin signatures of transcriptional promoters and enhancers in the human genome. Nat Genet 2007, 39:311-318

114. Hwang S, Son SW, Kim SC, Kim YJ, Jeong H, Lee D: A protein interaction network associated with asthma. J Theor Biol 2008, 252:722-731.

115. Politi AZ, Donovan GM, Tawhai MH, Sanderson MJ, Lauzon AM, Bates JH, Sneyd J: A multiscale, spatially distributed model of asthmatic airway hyper-responsiveness. J Theor Biol 2010, 266:614-624.

116. Lin CL, Tawhai MH, Hoffman EA: Multiscale image-based modeling and simulation of gas flow and particle transport in the human lungs. Wiley Interdiscip Rev Syst Biol Med 2013, 5:643-655.

117. Richens JL, Urbanowicz RA, Lunt EA, Metcalf R, Corne J, Fairclough L, O'Shea P: Systems biology coupled with label-free high-throughput detection as a novel approach for diagnosis of chronic obstructive pulmonary disease. Respir Res 2009, 10:29.

doi:10.1186/1939-4551-7-13

Cite this article as: ljaz et al: Systems biology approaches to understanding Epithelial Mesenchymal Transition (EMT) in mucosal remodeling and signaling in asthma. World Allergy Organization Journal 2014 7:13.

\section{Submit your next manuscript to BioMed Central and take full advantage of:}

- Convenient online submission

- Thorough peer review

- No space constraints or color figure charges

- Immediate publication on acceptance

- Inclusion in PubMed, CAS, Scopus and Google Scholar

- Research which is freely available for redistribution 